\title{
sciendo
}

\section{Technology Acceptance Model for the Internet Banking Acceptance in Split}

\author{
Marija Vuković, Snježana Pivac \\ University of Split, Faculty of Economics, Split, Croatia \\ Duje Kundid \\ SeekandHit, Split, Croatia
}

\section{Abstract}

Background: In today's dynamic environment, electronic banking and electronic commerce have become an inevitable aspect of financial services, so the question of acceptance and use of this kind of technology arises. Objectives: The aim of this research is to determine whether the motivation for using the Internet banking in the city of Split, Croatia, can be explained by perceived ease of use and perceived usefulness as the main elements of the technology acceptance model. Methods/Approach: For the purposes of the research, a survey analysis was applied to the sample of 282 working residents of Split. The gender and age structure of the sample was harmonized with the population to make the results more credible. In order to test the research hypothesis, logistic regression models were used. Results: The results confirmed that both elements of the technology acceptance model significantly influence the acceptance of the Internet banking in the city of Split. Conclusions: It is concluded that demographic and economic characteristics and perception of individuals affect the acceptance and use of the Internet banking in the city of Split. The results showed that both elements of the technology acceptance model influence the acceptance of the Internet banking.

Keywords: internet banking, logistic regression, survey analysis, technology acceptance model (TAM)

JEL classification: O39, C52, C83, G29

Paper type: Research article

Received: Jun 06, 2018

Accepted: Jan 03, 2019

Citation: Vuković, M., Pivac, S., Kundid, D. (2019), "Technology Acceptance Model for the Internet Banking Acceptance in Split", Business Systems Research, Vol. 10, No. 2, pp. 124-140.

DOI: 10.2478/bsri-2019-022

\section{Introduction}

Internet banking is an important banking service, which had numerous technological improvements in order to increase the number of users. It can be defined as a banking practice that allows customers to access and perform financial transactions on their bank accounts from their computer at any time they want. Thus, Internet banking allows customers to perform such transactions as transfer and payments, access of balance, viewing of statements of accounts, viewing of accounts details, customization print, printing of bank statements etc. (lbok and Ikoh, 2013). In order to explain the factors which influence the acceptance and use of Internet banking 
among the population, many authors have used the technology acceptance model (TAM), one of the most utilized models in studying information system acceptance. In TAM, system use (actual behaviour) is determined by perceived usefulness and perceived ease of use relating to the attitude toward use that relates to intention and finally to behaviour (Pikkarainen et al., 2004). In other words, if the user thinks that using of Internet banking is simple and useful, it should have a positive effect on his/her intention of actual use of Internet banking. It is expected that TAM can explain the acceptance and use of this service, considering the individual (demographic and psychological) characteristics of users.

The research hypothesis of this paper is that demographical and economical characteristics and perception of individuals affect the acceptance and use of Internet banking in the city of Split. The empirical research is based on a survey analysis, with questions related to both the main TAM elements and the individual characteristics of each respondent. The sample includes 282 working residents of Split. Gender and age structure of the sample was harmonized with the population to make the results more credible. Descriptive statistics was used to describe and present the sample structure and logistic regression models were used to test the hypotheses. Internet banking adoption was mostly studied for Asian, American and European countries with high number of users. Since there is not many research on the use of Internet banking in Croatia and Southeast European countries in general (Hanafizadeh et al., 2014), this research contributes to poor literature in that scientific area. It can be discovered if Internet banking adoption in Split, the second largest city in Croatia, is under the same influential factors as other countries, despite its lower number of Internet banking users. Likewise, it can be found if there are differences in the way those variables influence Internet banking adoption between the area of Split, Croatia, and countries with higher number of Internet banking users. These results can also help bank managers to understand the factors of Internet banking acceptance and to develop expansion strategy, especially in countries with lower number of users, like Croatia. The banks should also do more advertising to attract more residents to use their Internet banking service and consider educational programs in order to encourage older residents to adopt Internet banking. Additionally, they should consider offering more favourable conditions for their clients who use this service.

After the introduction, a theoretical framework and the literature review is provided, followed by the empirical analysis of application of the technology acceptance model in the field of Internet banking acceptance in the city of Split. After presenting the results, a conclusion and recommendation for future research is stated.

\section{Theoretical framework and literature review}

In today's dynamic environment where the clients of banks use online services more often, it is natural that the Internet has become the most important tool in business. It presents an important part of the banking business, especially in the context of Internet banking. There are many definitions of Internet banking itself, such as the distribution of the banking products and services using the Internet (Chavan, 2013). As stated earlier, it can also be defined as a banking practice which allows customers to access and perform financial transactions on their bank accounts from their computer at any time they want. According to Harris and Spence (2002), the development of an Internet electronic payment system provides opportunities for the creation of completely new sets of global and national trading relationships. Electronic banking and electronic commerce have become an inevitable aspect of financial services. User acceptance of technology has always been an important field of study. Many 
models have been proposed to explain and predict the use of a system, but the technology acceptance model (TAM), proposed by Fred Davis in his doctoral thesis in 1985, has captured the most attention (Chuttur, 2009). His model proposed that system use can be explained by user motivation, which is directly influenced by an external stimulus consisting of the actual system's features and capabilities. This model is widely used due to its focus on the information systems through the use of elements from psychological theory, in order to define the motivation for using an information system. According to Davis (1985), user's motivation can be explained by three factors: perceived ease of use (PEOU), perceived usefulness (PU) and attitude toward using the system. This model with all the relationships between the elements can be seen in figure 1.

Figure 1

Original TAM Proposed by Fred Davis

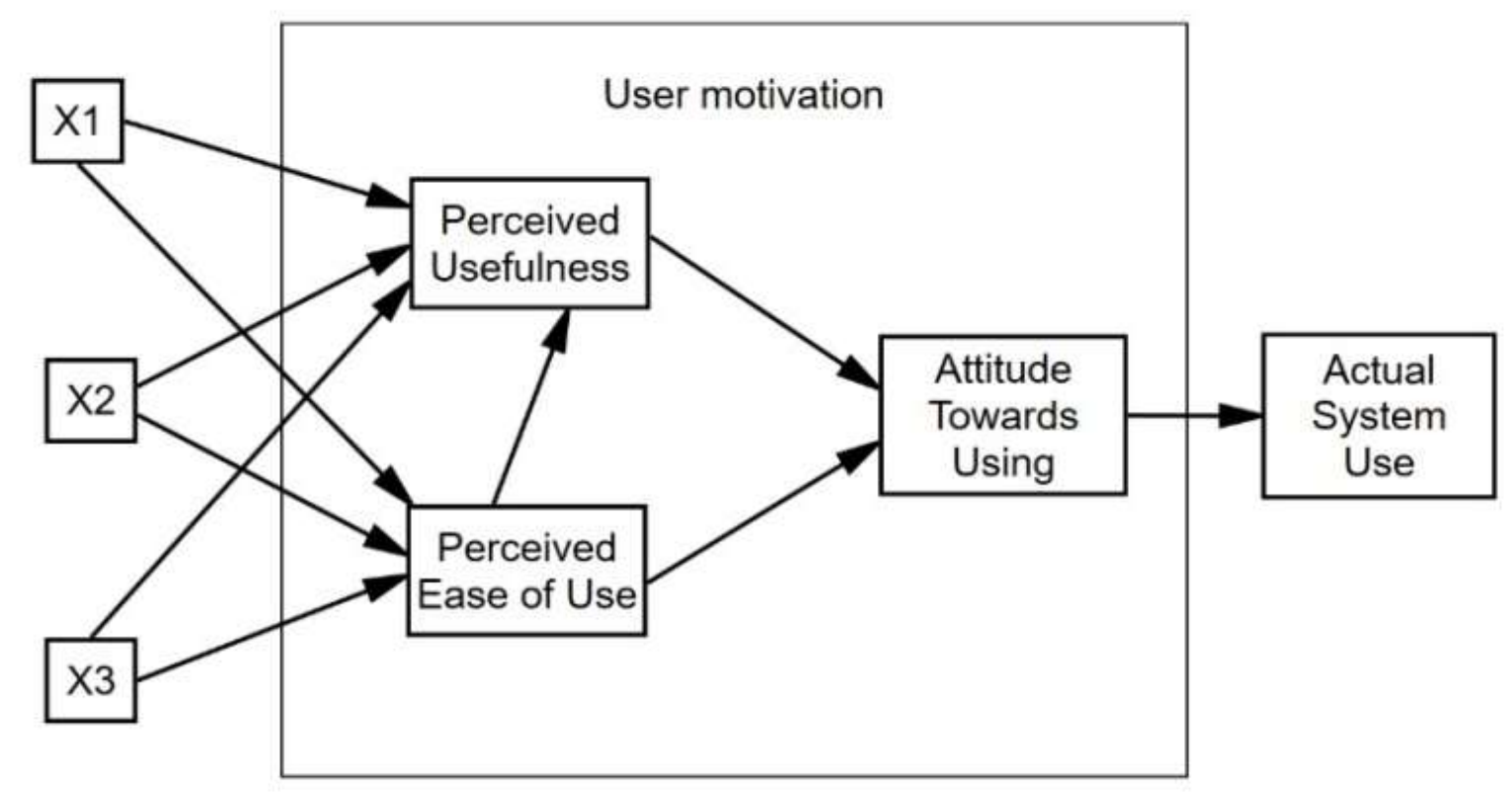
Design
Cognitive
Affective
Response
Behavioral
Response

Source: Davis (1985)

TAM later evolved, and in later experimentation stages, Davis (1985) refined his model to include other variables and modify the relationships between them. Other researchers also proposed some additions to TAM, so it became a leading model in explaining and predicting system use. Later development of the model included behavioural intention as a new variable directly influenced by the perceived usefulness and perceived ease of use of a system (Davis et al., 1989). Both of these elements of the original TAM were found to have a direct influence on behavioural intention, so the final TAM version actually had only one change compared to the original TAM, and that is the replacement of attitude toward using construct with the behavioural intention construct. The external variables influencing perceived usefulness and perceived ease of use can include system characteristics, sociodemographic characteristics, marketing efforts, training, user involvement in design etc. (Venkatesh and Davis, 1996). The final version of TAM is shown in figure 2. 
Figure 2

Final Version of TAM

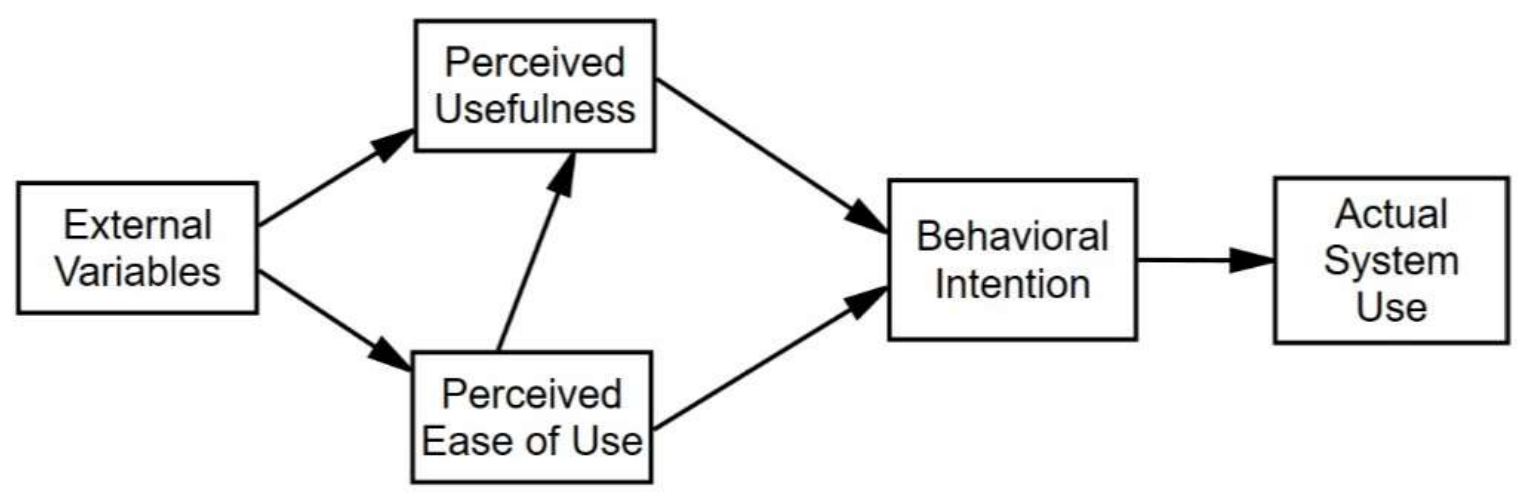

Source: Venkatesh and Davis (1996)

Although TAM consists of only two main elements, many authors have expanded and tested the model with various variables, with the purpose of getting a more accurate answer to the question what motivates users to use Internet banking. As explanatory variables in the model there are: openness of the potential user, web site design, information of use of Internet banking, perceived risk, state support, green concern etc. In most research, it was found that the perceived ease of use significantly affects the acceptance and use of Internet banking. However, for example Chong et al. (2010) have analysed Internet banking adoption in Vietnam by employing correlation and multiple regression analysis. They found that perceived ease of use does not affect the use of Internet banking, which is contrary to theoretical expectations. The authors explain that this unexpected result is probably caused by the fact that most of the respondents in the study are relatively young (age 21-30), so they mostly believe that they can learn online banking easily and ease of use will not be a barrier to their adoption of Internet banking. Kesharwani and Bisht (2012) have studied the adoption of Internet banking in India by exploratory and confirmatory factor analysis. They have also included social influences as a variable in the model and found that it significantly affects the use of Internet banking in India. It is hypothesized that, if a family member, friend or a colleague recommends the use of Internet banking as a useful banking channel, a person may also believe that it is actually useful, and in turn forms an intention to use it. They also concluded that the better and clearer web site design decreases the user's perceived risk. Yoon and Barker Steege (2013) have conducted a research through a survey among undergraduate students enrolled in a Principles of Information Systems for Management course in a southern public US university. They used partial least squares path modelling in the analysis and found that the openness of an individual affects the use of Internet banking, because they are more open to new experiences and technologies. It was also found that those who have high degree of green concern would use Internet banking even though they are strongly concerned about security issues. However, the results showed that green concern does not significantly affect the Internet banking use. Pikkarainen et al. (2004) developed a model indicating online banking acceptance among private banking customers in Finland by using confirmatory factor analysis. They concluded that the amount of information on Internet banking has a positive effect on consumer acceptance of Internet banking, because the more information of Internet banking advantages a person has, the more 
likely they will be encouraged to use it. Safeena et al. (2013) used hierarchical regression analysis to investigate the influence of perceived benefit, perceived impediment, social influence and demographic factors (gender and age) on Internet banking adoption in India, and confirmed their hypothesis that the influence exists. Yousafzai and Yani-de-Soriano's research in UK (2012) combined the construct of technology readiness with the technology acceptance model, as well as demographics, like age and gender, into one integrated framework. They used cluster and confirmatory factor analysis and their results indicated the importance of customer-specific factors in predicting actual behaviour, since they found that customers with varying levels of technology-related views and demographics hold different beliefs about technology. A research by Sadeghi and Farokhian (2011) also combined several models and theories (TAM, theory of reasoned action and theory of planned behaviour) to explore Internet banking adoption in Iran through structural equation modelling. They provided a model with seven factors: convenience, accessibility, accuracy, security, usefulness, bank image and web site design. The results showed that some factors have a significant statistical difference between males and females. Availability appears to be easier for females and males seem to be more suspicious of Internet banking. However, there was no difference in general satisfaction with electronic banking between males and females.

According to Eurostat data (2018), there is a growing trend of Internet banking users. In most of the European countries, the percentage of users in 2017 was above $50 \%$, where Scandinavian countries and the countries of Benelux are in the lead with more than $70 \%$, and some with even more than $90 \%$ of Internet banking users. On the other hand, most of the Southeast European countries, including Croatia, are at the bottom of the list, where Bulgaria and Montenegro had only $5 \%$ and $4 \%$ of users in 2017. Croatia had $33 \%$ of users in 2017 , which is 5 percentage points less than the previous year. There is not many research regarding Internet banking adoption in this area, since most of the research was done in Asian and North American countries, while the research in European countries was mostly focused on the countries with higher number of Internet banking users (Hanafizadeh et al., 2014).

Some research on Internet banking adoption in countries with lower number of users include, for example, segmentation study by Patsiotis et. al (2012) by using cluster analysis on a sample of Greek customers. They identified three segments, where the description of their profiles is based on customer perceptions of the service and general usage data. It was found that adopters and non-adopters have different characteristics, and only income was found to be associated with segment membership. Gounaris and Koritos (2008) also did a research in Greece through confirmatory factor analysis and logistic regression analysis, and they concluded that relative advantage and ease of use, as well as demographics and psychographics, such as hedonic-orientation, influence the final outcome of consumers' adoption decision. Guraau (2002) did a thorough analysis of the Romanian market environment and banking sector through secondary data sources, and conducted semi-structured interviews with bank managers and other personnel in order to explore online banking situation in Romania and the strategies for its successful implementation and development. Those strategies were found to be influenced by many interrelated factors and institutions, such as the quality and security of Internet network, the level of Internet knowledge, the government support, the Internet strategy of the bank and the quality and reliability of online banking services. In Poland, a study using logistic regression showed that the behaviour of Polish internet users has similar traits to that of consumers in more developed countries. The factors which have found to influence online banking adoption included: perceived level of security, demographic variables 
(gender, urbanisation of the area of residence, educational attainment and age) and advertising (Polasik and Wisniewski, 2009). Makarević (2016) used descriptive statistics to analyse and compare perceptions of clients of Bosnia and Herzegovina and those of Croatia about information technology security in online banking. The results indicate that Croatian clients think that banks are able to protect their privacy completely and that banks are doing their best to improve confidentiality of online transactions, while clients of Bosnia and Herzegovina think the opposite. They agree and trust to bank when it comes to control aspect, but there is still a certain amount of feeling unsafe in psychology of people, which could be the reason why there is no significant increase in trend line of electronic banking development of Bosnia and Herzegovina. One of the newest researches by Liébana-Cabanillas et al. (2017) studied the key factors that influence consumers' adoption of mobile commerce in the Republic of Serbia through a SEM-neural network approach. They developed a new model with six potential predictors of behavioural intention (usefulness, ease of use, trust, mobility, customization and customer involvement), where customization and customer involvement turned out to be the strongest predictors of behavioural intention.

To summarize, most of the previous research used perceived ease of use and perceived usefulness as predictors of Internet banking adoption in their models. Their results have generally shown a positive influence of those factors on Internet banking adoption, with the exception of Chong et al. (2010), who found that perceived ease of use does not affect the use of Internet banking. Many authors have also included demographic and other characteristics of users in their research. Among those characteristics, the most commonly used variables are gender and age (Safeena et al., 2014; Yousafzai and Yani-de-Soriano, 2012; Sadeghi and Farokhian, 2011 ; Polasik and Wisniewski, 2009), while Patsiotis et. al (2012) also included income as a predictor variable. Polasik and Wisniewski (2009) not only observed gender and age, but they observed many other variables and found that, apart from gender and age, demographic characteristics which influence online banking adoption are Internet experience, income, urbanisation of the area of residence and educational attainment. However, they measured age and income as binary variables. In order to get more accurate results, it is necessary to treat those variables as numerical, since they can vary a lot.

Not many studies have been conducted on Internet banking adoption in Croatia and countries with lower number of users in general, especially regarding TAM applicability. Therefore, this research aims to determine whether the motivation for using Internet banking in the city of Split, Croatia, can be explained by perceived ease of use and perceived usefulness, as well as demographic and economic characteristics of users. In this way, it can be discovered whether Internet banking adoption in Split, the second largest city in Croatia, is under the same influential factors as other countries, despite its lower number of Internet banking users.

Considering the aim of this research, the main hypothesis and three auxiliary hypotheses are proposed:

H1. Demographic and economic characteristics and perception of individuals affect the acceptance and use of internet banking in the city of Split.

Hla. Demographic and economic characteristics (gender, age, level of education, income, Internet experience) affect the use of Internet banking.

Hib. Perceived ease of use of Internet banking has a positive effect on the acceptance of Internet banking.

Hlc. Perceived usefulness of Internet banking has a positive effect on the acceptance of Internet banking. 


\section{Methodology}

\section{Research instrument}

For the purposes of the research, a survey analysis was applied, with questions related to both the main TAM elements and the individual characteristics of each respondent. The research was carried out in the period of April to July 2017 by sending the electronic version of the survey through social networks and e-mail, as well as direct distributing of the printed version of the survey to people who don't use the Internet (Kundid, 2017).

The survey consists of 16 questions. It is divided in several groups of questions relating to perceived ease of use and perceived usefulness of Internet banking, as well as questions about the individual characteristics of respondents. Through the questions relating to the intention of continuing or starting to use Internet banking, application of TAM will be tested. The survey was based on previous research. The questions about frequency and length of Internet banking usage and frequency of using certain Internet banking functionalities were formed according to Tokić (2014). The questions regarding perceived ease of use and perceived usefulness were formed according to Pikkarainen et al. (2004) and Yoon and Barker Steege (2013), and the question about the intention of Internet banking adoption was formed according to Chong et al. (2010).

For the answers to the survey questions regarding the agreement with certain statements measuring PEOU and PU, a 1-5 Likert scale (1 =strongly disagree, 5=strongly agree) was used, as is usual in all levels of the Croatian education system ( $1=$ negative grade, $5=e x c e l l e n t$ grade) and for social research. The research instrument description with these variables is shown in table 1.

Table 1

Research Instrument Description

\begin{tabular}{|c|c|}
\hline Code & Item \\
\hline PEOU1 & $\begin{array}{l}\text { I believe that the use of Internet banking is easy to learn (it would be easy to } \\
\text { learn) }\end{array}$ \\
\hline PEOU2 & $\begin{array}{l}\text { I believe that the use of Internet banking is clear and understandable (it would } \\
\text { be clear and understandable to me) }\end{array}$ \\
\hline PEOU3 & I believe that Internet banking is easy to use (it would be easy for me to use) \\
\hline PEOU4 & $\begin{array}{l}\text { I believe that it is easy to gain the skills of Internet banking use (it would be easy } \\
\text { for me to gain Internet banking skills) }\end{array}$ \\
\hline PU1 & I consider Internet banking useful \\
\hline PU2 & I believe that Internet banking eliminates spatial limitations \\
\hline PU3 & I believe that Internet banking saves time \\
\hline PU4 & I believe that Internet banking saves money \\
\hline PU5 & I believe that the use of Internet banking increases productivity \\
\hline
\end{tabular}

Source: Authors' work

\section{Data}

The research is based on the working population in Split. The working population is the total population in a region that is considered to be able and likely to work, and it includes those who are aged 15 to 64. The total working population of Split, according to the latest census in 2011 , was 121.242 residents (Croatian Bureau of Statistics, 2017). According to 0.95 confidence interval and 0.05 margin of error, a sample size of 383 was determined. However, not all surveys were filled out. The final sample includes 282 working residents of Split, which corresponds the sample size with 0.90 confidence level and 0.05 margin of error. 
Gender and age structure of the sample was harmonized with the population to make the results more credible. Thus, the sample included $51.42 \%$ of female and $48.58 \%$ of male respondents. Those respondents were equally distributed in each of the five different age groups. Therefore, the sample can be considered a combination of stratified and quota sample, since the population was first divided into separate strata, and then a random sample from each stratum is taken in a number proportional to the stratum's size when compared to the population (Teddlie and Yu, 2007). In table 2, the sample structure by gender and age is shown.

Table 2

Sample Structure by Gender and Age

\begin{tabular}{|c|c|c|c|c|}
\hline & & Female & Male & Total \\
\hline$\leq 24$ years & $\begin{array}{l}\text { No } \\
\text { (\%) }\end{array}$ & $\begin{array}{l}28 \\
(9.9 \%)\end{array}$ & $\begin{array}{l}24 \\
(8.5 \%)\end{array}$ & $\begin{array}{l}52 \\
(18.4 \%)\end{array}$ \\
\hline $25-34$ years & $\begin{array}{l}\text { No } \\
\text { (\%) }\end{array}$ & $\begin{array}{l}27 \\
(9.6 \%)\end{array}$ & $\begin{array}{l}31 \\
(11.0 \%)\end{array}$ & $\begin{array}{l}58 \\
(20.6 \%)\end{array}$ \\
\hline $35-44$ years & $\begin{array}{l}\text { No } \\
\text { (\%) }\end{array}$ & $\begin{array}{l}30 \\
(10.6 \%)\end{array}$ & $\begin{array}{l}26 \\
(9.2 \%)\end{array}$ & $\begin{array}{l}56 \\
(19.9 \%)\end{array}$ \\
\hline $45-54$ years & $\begin{array}{l}\text { No } \\
(\%)\end{array}$ & 30 & 28 & $\begin{array}{l}58 \\
(20.6 \%)\end{array}$ \\
\hline $55-64$ years & $\begin{array}{l}\text { No } \\
\text { (\%) }\end{array}$ & $\begin{array}{l}30 \\
(10.6 \%)\end{array}$ & $\begin{array}{l}28 \\
(9.9 \%)\end{array}$ & $\begin{array}{l}58 \\
(20.6 \%)\end{array}$ \\
\hline Total & $\begin{array}{l}\text { No } \\
\text { (\%) }\end{array}$ & $\begin{array}{l}145 \\
(51.4 \%)\end{array}$ & $\begin{array}{l}137 \\
(48.6 \%)\end{array}$ & \\
\hline
\end{tabular}

Source: Authors' work according to the survey analysis data (2017)

Most of the respondents are highly educated (56.7\%), while the rest have primary and secondary education (43.3\%). The highest number of respondents (30.1\%) have monthly income from 2501 to 5000 HRK, followed by those with the income from 5001 to 7500 HRK (27\%). Only $11 \%$ of the respondents have monthly income above 10000 HRK. Majority of the respondents have been using the Internet longer than 11 years (49.3\%), while only $5.7 \%$ of them have been using the Internet for 2 years or less.

\section{Statistics}

Data collected from the survey will be analysed through several statistical methods by using statistical packages SPSS 23.0 and Stata 13. Firstly, descriptive statistics of Internet banking functionalities usage will be shown, in order to understand the main features of Internet banking that people are interested in using.

Afterwards, exploratory factor analysis will be used to define the underlying structure among the variables in the analysis. Since there are several variables representing perceived ease of use and perceived usefulness, it is possible that all these variables become correlated. For that reason, it is necessary to manage these variables and group highly correlated variables together, where it is assumed that there will be two factors, one for each of the TAM element (PEOU and PU). In this research, for the purposes of further hypothesis testing, new composite measures will be created to represent each group of variables (Hair et al., 2010).

In addition, reliability analysis will be conducted to determine the extent to which the variables are consistent in their values using Cronbach's alpha coefficients as measures of reliability (Hair et al., 2010).

Finally, logistic regression models will be used to test the research hypothesis. Two models will be tested, one for each of the TAM element. The dependent variable for 
both models will be Internet banking adoption, which is a binary (dichotomous) variable. Independent variables for the first model will be perceived ease of use, demographic and economic characteristics, while perceived usefulness will be an independent variable in the second model, along with demographic and economic characteristics of users. The variables perceived ease of use and perceived usefulness will be used in the form of composite measures created from factor analysis.

\section{Empirical results and discussion}

\section{Descriptive statistics}

The results of frequency of using certain functionalities of Internet banking are presented in table 3. Since 189 respondents use the Internet, and 93 respondents don' $t$ use it, the results refer to these 189 Internet banking users. As it can be seen, most of the respondents use Internet banking for the insights in the balance and the transactions per account, as well as for domestic and foreign payments. These results are not surprising, since these insights are free and do not lead to outflows from the account. In addition, people prefer to have control over their money by checking all of the transactions per their account. The next most frequently used functionality is domestic and foreign payments, which is expected, since an average consumer pays bills and shops a few times a month, and it is easier, faster and time saving to pay via Internet banking. It has previously been shown that this is the usual frequency of banking activities usage, not only in Croatia (Milanović Glavan and Ćibarić, 2015), but also around the world, for example in China (Yiu et al., 2007) and New Zealand (Chung and Paynter, 2002). This can also be explained by the fact that the main reason that the respondents provided for using Internet banking is the time saving, since they don' $t$ have to be physically present in a bank, as well as the accessibility of the service 24 hours a day.

\section{Table 3}

Frequency of Using Certain Internet Banking Functionalities

\begin{tabular}{|c|c|c|c|c|c|c|c|}
\hline & & $\begin{array}{l}\text { Using } \\
\text { Insights in } \\
\text { the Balance } \\
\text { and the } \\
\text { Transactions } \\
\text { per } \\
\text { Account }\end{array}$ & $\begin{array}{l}\text { Domestic } \\
\text { and } \\
\text { Foreign } \\
\text { Payments }\end{array}$ & $\begin{array}{l}\text { Buying } \\
\text { Foreign } \\
\text { Exchange } \\
\text { via } \\
\text { Internet } \\
\text { Banking }\end{array}$ & $\begin{array}{l}\text { Depositing } \\
\text { via } \\
\text { Internet } \\
\text { Banking }\end{array}$ & $\begin{array}{l}\text { Account } \\
\text { Statement } \\
\text { Downloading } \\
\text { via Internet } \\
\text { Banking }\end{array}$ & $\begin{array}{l}\text { Purchase } \\
\text { of Shares } \\
\text { in Funds } \\
\text { via } \\
\text { Internet } \\
\text { Banking }\end{array}$ \\
\hline $\begin{array}{l}\text { Almost Every } \\
\text { Day }\end{array}$ & $\begin{array}{l}\text { No } \\
\text { (\%) }\end{array}$ & $\begin{array}{l}38 \\
(20.1 \%)\end{array}$ & $\begin{array}{l}11 \\
(5.8 \%)\end{array}$ & $\begin{array}{l}1 \\
(0.5 \%)\end{array}$ & $\begin{array}{l}1 \\
(0.5 \%)\end{array}$ & $\begin{array}{l}6 \\
(3.2 \%)\end{array}$ & $\begin{array}{l}1 \\
(0.5 \%)\end{array}$ \\
\hline $\begin{array}{l}\text { A Few Times a } \\
\text { Week }\end{array}$ & $\begin{array}{l}\text { No } \\
\text { (\%) }\end{array}$ & $\begin{array}{l}64 \\
(33.9 \%)\end{array}$ & $\begin{array}{l}39 \\
(20.6 \%)\end{array}$ & $\begin{array}{l}4 \\
(2.1 \%)\end{array}$ & $\begin{array}{l}0 \\
(0.0 \%)\end{array}$ & $\begin{array}{l}5 \\
(2.6 \%)\end{array}$ & $\begin{array}{l}0 \\
(0.0 \%)\end{array}$ \\
\hline $\begin{array}{l}\text { A Few Times a } \\
\text { Month }\end{array}$ & $\begin{array}{l}\text { No } \\
\text { (\%) }\end{array}$ & $\begin{array}{l}66 \\
(34.9 \%)\end{array}$ & $\begin{array}{l}96 \\
(50.8 \%)\end{array}$ & $\begin{array}{l}17 \\
(9.0 \%)\end{array}$ & $\begin{array}{l}1 \\
(0.5 \%)\end{array}$ & $\begin{array}{l}25 \\
(13.2 \%)\end{array}$ & $\begin{array}{l}3 \\
(1.6 \%)\end{array}$ \\
\hline $\begin{array}{l}\text { Less than } \\
\text { Once a Month }\end{array}$ & $\begin{array}{l}\text { No } \\
\text { (\%) }\end{array}$ & $\begin{array}{l}20 \\
(10.6 \%)\end{array}$ & $\begin{array}{l}21 \\
(11.1 \%)\end{array}$ & $\begin{array}{l}54 \\
(28.6 \%)\end{array}$ & $\begin{array}{l}44 \\
(23.3 \%)\end{array}$ & $\begin{array}{l}81 \\
(42.9 \%)\end{array}$ & $\begin{array}{l}10 \\
(5.3 \%)\end{array}$ \\
\hline Never & $\begin{array}{l}\text { No } \\
(\%)\end{array}$ & $\begin{array}{l}1 \\
(0.5 \%)\end{array}$ & $\begin{array}{l}22 \\
(11.6 \%)\end{array}$ & $\begin{array}{l}113 \\
(59.8 \%)\end{array}$ & $\begin{array}{l}143 \\
(75.7 \%)\end{array}$ & $\begin{array}{l}72 \\
(38.1 \%)\end{array}$ & $\begin{array}{l}175 \\
(92.6 \%)\end{array}$ \\
\hline Total & $\begin{array}{l}\text { No } \\
(\%)\end{array}$ & $\begin{array}{l}189 \\
(100 \%)\end{array}$ & $\begin{array}{l}189 \\
(100 \%)\end{array}$ & $\begin{array}{l}189 \\
(100 \%)\end{array}$ & 189 (100\%) & $\begin{array}{l}189 \\
(100 \%)\end{array}$ & $\begin{array}{l}189 \\
(100 \%)\end{array}$ \\
\hline
\end{tabular}

Source: Authors' work according to the survey analysis data (2017)

\section{Factor analysis}

In order to test whether demographical and economical characteristics and perception of individuals affect the acceptance and use of Internet banking in the 
city of Split, three auxiliary hypotheses were formed, as stated earlier. Using these hypotheses, the applicability of TAM in the context of Internet banking will be tested through logistic regression models. Two models will test two auxiliary hypotheses regarding the impact of PEOU and PU on Internet banking adoption, while the first auxiliary hypothesis regarding the impact of demographical and economical characteristics on Internet banking adoption will be tested through both of these regression models, since these variables will be used as control variables in both models. Before testing these models, it is necessary to conduct factor analysis to form composite measures for PEOU and PU. The results of KMO and Bartlett's test are shown in table 4. These measures of sampling adequacy evaluate how strongly an item is correlated with other items in the EFA correlation matrix. KMO value ranges from 0 to 1 , and the value of 0.50 is considered suitable for factor analysis. Bartlett's test of Sphericity provides a chi-square output. It indicates that the item correlation matrix is not an identity matrix. Therefore, chi-square value must be significant for factor analysis to be suitable (Taherdoost et al., 2014). The results for this sample show a very high $\mathrm{KMO}$ value (0.924) and a significant chi-square value ( $\mathrm{p} \leq 0.001)$, so it can be concluded that factor analysis is suitable.

Table 4

KMO and Bartlett's Test Results

\begin{tabular}{llr}
\hline Kaiser-Meyer-Olkin Measure of Sampling Adequacy & 0.924 \\
\hline Bartlett's Test of Sphericity & Approx. Chi-Square & 3859.214 \\
& df & 36 \\
P-value & $\leq 0.001$ \\
\hline Source: Authors' work according to the survey analysis data (2017)
\end{tabular}

The principal components analysis with Varimax rotation method for extracting two factors was used in this study. Principal components analysis considers the total variance and derives factors that contain small proportions of unique variance and, in some cases, error variance (Hair et al., 2010). It is a data reduction approach, suitable for reducing the number of items of the research instrument (Taherdoost et al., 2014). The results of factor analysis show two factors: perceived ease of use, consisting of items PEOU 1, PEOU2, PEOU3 and PEOU4, and perceived usefulness, which consists of items PU1, PU2, PU3, PU4 and PU5. The results indicate that all of the items should be retained, since they all have high factor loadings. Costello and Osborne (2005) recommended using cut-off values of 0.40 to 0.70 , and stated that item communalities are considered high if they are 0.8 or greater, which is the case in this research. It can also be concluded that both of the extracted factors are solid, because all of the factor loadings are above 0.50. These results can be seen in table 5 . 
Table 5

Rotated Component Matrix for Two Factors

\begin{tabular}{lll}
\hline Item & Factor \\
\hline & $\mathbf{1}$ & $\mathbf{2}$ \\
\hline PEOU1 & & 0.897 \\
PEOU2 & & 0.890 \\
PEOU3 & & 0.896 \\
PEOU4 & & 0.892 \\
\hline PU1 & 0.851 & \\
PU2 & 0.850 & \\
PU3 & 0.857 & \\
PU4 & 0.822 & \\
PU5 & 0.840 & \\
\hline
\end{tabular}

Source: Authors' work according to the survey analysis data (2017)

\section{Reliability analysis}

Reliability analysis was conducted to determine the extent to which the variables are internally consistent in their values using Cronbach's alpha coefficients. Many authors consider an alpha of 0.65 to 0.70 adequate, while some consider the value of 0.60 adequate. Therefore, there are different reports about the acceptable values of alpha, mostly ranging from 0.70 to even 0.95 (Tavakol and Dennick, 2011).

As it can be seen in table 6, Cronbach's alpha coefficients for both factors are very high, above 0.95, which shows internal consistency of the items. The corrected itemtotal correlations are all greater than 0.40 , which shows an acceptable scale. Besides, Cronbach's alpha of each factor if any of its items is deleted is less than the factor's Cronbach's Alpha, suggesting that none of the items should be removed from the factor (Shelby, 2011).

Table 6

Cronbach's Alpha Reliability Test for Items of Factors

\begin{tabular}{lllll}
\hline Factor & Variables & $\begin{array}{l}\text { Cronbach's } \\
\text { alpha }\end{array}$ & $\begin{array}{l}\text { Corrected Item-Total } \\
\text { Correlation }\end{array}$ & $\begin{array}{l}\text { Cronbach's Alpha if } \\
\text { Item Deleted }\end{array}$ \\
\hline PEOU & PEOU1 & 0.985 & 0.960 & 0.979 \\
& PEOU2 & & 0.954 & 0.981 \\
& PEOU3 & & 0.962 & 0.979 \\
& PEOU4 & & 0.964 & 0.978 \\
\hline & PU1 & 0.956 & 0.898 & 0.943 \\
& PU2 & & 0.899 & 0.943 \\
& PU3 & & 0.907 & 0.941 \\
& PU4 & & 0.822 & 0.955 \\
\hline
\end{tabular}

Source: Authors' work according to the survey analysis data (2017)

\section{Logistic regression models}

In order to test the research hypothesis, logistic regression models were used. Robust standard errors were calculated to control for heteroscedasticity (Mood, 2010). One model was used for each of the TAM elements, PEOU and PU. The dependent variable for both models is Internet banking (IB) adoption, a binary (dichotomous) variable. This variable is represented by the survey question "Do You Intend to Start Using or Continuing to Use Internet Banking Service in the Future?", with two possible answers (no or yes). PEOU and PU are the main independent variables, each for one model, 
along with demographic and economic characteristics of users. In regression models, perceived ease of use and perceived usefulness are used in the form of composite measures created from previously conducted factor analysis.

The results of both regression models are shown in table 7. As it can be seen, all variables, except for gender, show significant influence. Perceived ease of use positively affects IB adoption, i.e. the respondents who show higher level of agreement with statements that Internet banking is easy to learn, is clear and understandable and that it is easy to use and gain the skills for using it, increase the probability of IB adoption. Perceived usefulness also has a positive impact, meaning that the respondents who show higher level of agreement with the statements of Internet banking usefulness, such as eliminating spatial limitations, productivity increasing, and time and money saving, increase the probability of IB adoption. Age has a negative impact on IB adoption, which means that if the respondents are older, it decreases the probability of their IB adoption. Level of education also negatively affects IB adoption. It is a binary variable where one group represents primary and secondary education, and the other represents higher education. The first group is chosen as the reference category. Therefore, if the respondent has only primary or secondary education, it decreases the probability of IB adoption. However, the impact of level of education is not significant in the second model. Internet usage and income have a positive impact, which means that if the respondents have higher income and have been using the Internet for longer time, it increases the probability of their IB adoption.

Table 7

Logistic Regression Results (with Robust Standard Errors)

\begin{tabular}{|c|c|c|c|c|}
\hline & Model 1 & & Model 2 & \\
\hline IB adoption & $\begin{array}{l}\text { Coefficient ( } p- \\
\text { value) }\end{array}$ & $\begin{array}{l}\text { Odds } \\
\text { Ratio }\end{array}$ & $\begin{array}{l}\text { Coefficient ( } p- \\
\text { value) }\end{array}$ & $\begin{array}{l}\text { Odds } \\
\text { Ratio }\end{array}$ \\
\hline PEOU & $\begin{array}{l}0.607^{* * *} \\
(0.001)\end{array}$ & 1.835 & --- & --- \\
\hline PU & --- & --- & $\begin{array}{l}0.674^{* * *} \\
(0.001)\end{array}$ & 1.962 \\
\hline Gender & $\begin{array}{l}-0.353 \\
(0.369)\end{array}$ & 0.703 & $\begin{array}{l}-0.489 \\
(0.204)\end{array}$ & 0.613 \\
\hline Age & $\begin{array}{l}-0.0606^{* * *} \\
(0.003)\end{array}$ & 0.941 & $\begin{array}{l}-0.0368^{*} \\
(0.056)\end{array}$ & 0.964 \\
\hline $\begin{array}{l}\text { Level of } \\
\text { education }\end{array}$ & $\begin{array}{l}-0.826^{* *} \\
(0.049)\end{array}$ & 0.438 & $\begin{array}{l}-0.715 \\
(0.112)\end{array}$ & 0.489 \\
\hline Internet usage & $\begin{array}{l}0.195^{* * *} \\
(\leq 0.001)\end{array}$ & 1.215 & $\begin{array}{l}0.212^{* * *} \\
(\leq 0.001)\end{array}$ & 1.236 \\
\hline Income & $\begin{array}{l}0.000205^{* *} \\
(0.016)\end{array}$ & 1.000205 & $\begin{array}{l}0.000188^{* *} \\
(0.011)\end{array}$ & 1.000188 \\
\hline Constant & $\begin{array}{l}2.187^{*} \\
(0.053)\end{array}$ & & $\begin{array}{l}1.162 \\
(0.305)\end{array}$ & \\
\hline$N$ & 282 & & 282 & \\
\hline Pseudo R2 & 0.3325 & & 0.3385 & \\
\hline
\end{tabular}

Source: Authors' work according to the survey analysis data (2017) Note: ${ }^{*} \mathrm{p}<0.10,{ }^{* *} \mathrm{p}<0.05,{ }^{* * *} \mathrm{p}<0.01$

From these results, it can be concluded that the perceived ease of use and perceived usefulness positively affect the acceptance of Internet banking. These results were also confirmed in previous research, since the more a person agrees that Internet banking is useful and easy to use, he/she is more motivated in starting or 
continuing to use it. According to this, TAM in the context of Internet banking over the working population of Split is applicable. Regarding the demographic and economic characteristics, it was found that the hypothesis is partially confirmed, since the impact of gender is not significant in any model, and level of education is significant in one of the two proposed models. However, there were other demographic and other characteristics, which showed high significance in both models. Therefore, as all three auxiliary hypotheses are confirmed, the main hypothesis that demographic and economic characteristics and perception of individuals affect the acceptance and use of Internet banking in the city of Split is accepted.

\section{Conclusion}

In this paper, the aim was to determine if the motivation for the use of Internet banking in the city of Split, Croatia can be explained by perceived ease of use and perceived usefulness, as the main elements of the technology acceptance model. For the purposes of the research, a survey analysis was applied, with questions related to both of the main TAM elements and the individual characteristics of each respondent, on a sample of 282 working residents of Split. Logistic regression models were used to test the hypothesis. The findings revealed the existence of the influence of perceived ease of use, perceived usefulness, and demographic and economic characteristics on Internet banking adoption in Split. Specifically, it was found that mostly younger respondents with higher level of education, greater experience of using the Internet, higher level of income, and higher level of agreement with statements of Internet banking ease of use and its usefulness, are more likely to adopt Internet banking.

These findings are in accordance with previous research, which used perceived ease of use and perceived usefulness, as well as demographic and other characteristics as predictors of Internet banking adoption in their models. Most of the research has found a positive influence of those factors on Internet banking adoption, with the exception of Chong et al. (2010), who found that perceived ease of use does not affect the use of Internet banking. As for demographic and other characteristics of users, the most commonly used variables in previous research were gender and age (Safeena et al., 2014; Yousafzai and Yani-de-Soriano, 2012; Sadeghi and Farokhian, 2011; Polasik and Wisniewski, 2009), with some additions of other variables, such as income (Patsiotis et. al, 2012), Internet experience, urbanisation of the area of residence and educational attainment (Polasik and Wisniewski, 2009). Other authors have also observed security and perceived risk, social influence, web site design, personality traits etc. as predictors of Internet banking adoption (Yoon and Barker Steege, 2013; Pikkarainen et al., 2004; Safeena et al., 2014; Kesharwani and Bisht, 2012; Gounaris and Koritos, 2008; Makarević, 2016). It was shown that all of these variables affect Internet banking adoption. In contrast to previous research, this research is focused on testing TAM through its main elements, perceived ease of use and perceived usefulness, as well as some of the demographic and economic characteristics of users. This research has treated age and income as numerical variables, unlike Polasik and Wisniewski (2009), who measured them as binary variables. Since Internet experience has not commonly been used as an influential variable, this research has included it in its models as an important predictor of IB adoption.

Since there is not many research on Internet banking adoption in Croatia and countries with lower number of users in general, especially regarding TAM applicability, this research contributes to poor literature in that scientific area. Therefore, by exploring whether the motivation for using Internet banking in the city of Split can be explained by perceived ease of use, perceived usefulness, and 
demographic and economic characteristics of users, it is discovered that Internet banking adoption in Split, the second largest city in Croatia, is under the same influential factors as other countries, despite its lower number of Internet banking users. It can also be found that there are no great differences in the way those variables influence IB adoption between the area of Split, Croatia, and countries with higher number of Internet banking users. Only gender does not significantly affect IB adoption in Split, unlike in other countries. These results can also help bank managers to understand the factors of Internet banking acceptance and to develop expansion strategy, especially in countries with lower number of users. Since it was concluded that Internet banking users are mostly younger and higher educated residents, with greater experience of Internet usage and higher income, the banks should consider various marketing campaigns to attract more residents to use their Internet banking service. They can also consider educational programs in order to encourage older residents to adopt Internet banking and offer more favourable conditions for their clients who use this service.

However, there are some limitations of the research, related to the sample. Since the printed version of the survey was directly distributed to people who don't use the Internet, some of the acquaintances were surveyed, so the sample is not entirely unbiased. In addition, a research on a wide area of several Croatian cities should be conducted in order to generalize the findings of the research for the whole country. For further research, it is recommended to increase the sample size for higher test significance and to test TAM additionally with more explanatory variables. The methodology could also be expanded to structural equation modelling. Improved understanding of factors of Internet banking acceptance and the consequential expansion strategies of banks should result in a wider application of Internet banking service. This would lead to more efficient banking and business development, which is beneficial for both banks and their clients. Future research in this area and increased application of Internet banking service should provide numerous benefits for all parties involved.

\section{References}

1. Chavan, J. (2013), "Internet banking - benefits and challenges in an emerging economy", International Journal of Research in Business, Vol. 1, No. 1, pp. 19-26.

2. Chong, A. Y., Ooi, K., Lin, B., Tan, B. (2010), "Online banking adoption: an empirical analysis", International Journal of Bank Marketing, Vol. 28, No. 4, pp. 267-287.

3. Chung, W., Paynter, J. (2002), "An Evaluation of Internet Banking in New Zealand", in proceedings of the 35th Hawaii International Conference on System Sciences, Big Island, Hawaii, IEEE Computer Society Washington, DC, USA, pp. 2410-2419.

4. Chuttur, M. Y. (2009), "Overview of the Technology Acceptance Model: Origins, Developments and Future Directions", Sprouts: Working Papers on Information Systems, Vol. 9, No. 37, Indiana University, USA.

5. Costello, A. B., Osborne, J. W. (2005), "Best practices in exploratory factor analysis: four recommendations for getting the most from your analysis", Practical Assessment Research \& Evaluation, Vol. 10, No. 7, pp. 1-9.

6. Croatian Bureau of Statistics (2017), "Census of Population, Households and Dwellings 2011 ", available at: https://www.dzs.hr/Hrv_Eng/publication/2012/SI-1468.pdf

(20 September 2016).

7. Davis, F. (1985), "A technology acceptance model for empirically testing new end-user information systems: theory and results", Doctoral thesis, MIT Sloan School of Management, Cambridge, MA.

8. Davis, F. D., Bagozzi, R. P., Warshaw, P. R. (1989), "User acceptance of computer technology: a comparison of two theoretical models", Management Science, Vol. 35, No. 8, pp. 982-1003. 
9. Eurostat (2018), "Individuals using the internet for internet banking", available at: http://ec.europa.eu/eurostat/tgm/table.do?tab=table\&init=1 \&plugin=1 \&pcode=tin00099 \&language $=e n$ (17 July 2018).

10. Gounaris, S., Koritos, C. (2008), "Investigating the drivers of internet banking adoption decision: A comparison of three alternative frameworks", International Journal of Bank Marketing, Vol. 26, No. 5, pp. 282-304.

11. Guraau, C. (2002), "Online banking in transition economies: the implementation and development of online banking systems in Romania", International Journal of Bank Marketing, Vol. 20, No. 6, pp. 285-296.

12. Hair, J. F., Black, W. C., Babin, B. J., Anderson, R. E. (2010), Multivariate Data Analysis, 7th Edition, Pearson, Upper Saddle River, NJ Prentice Hall.

13. Hanafizadeh, P., Keating, B. W., Khedmatgozar, H. R. (2014), "A systematic review of Internet banking adoption", Telematics and Informatics, Vol. 31, No. 3, pp. 492-510.

14. Harris, L., Spence, L. J. (2002), "The ethics of Ebanking", Journal of Electronic Commerce Research, Vol. 3, No. 2, pp. 59-66.

15. Ibok, N., Ikoh, I. M. (2013), "Determinants of Customers Satisfaction with Internet banking Services", British Journal of Arts and Social Sciences, Vol. 14, No. 2, pp. 178-185.

16. Kesharwani, A., Bisht, S. S. (2012), "The impact of trust and perceived risk on Internet banking adoption in India: An extension of technology acceptance model", International Journal of Bank Marketing, Vol. 30, No. 4, pp. 303-322.

17. Kundid, D. (2017), "Factors of acceptance of Internet banking among the population in the City of Split", Master thesis, University of Split, Faculty of Economics, Business and Tourism, available at: https://repozitorij.efst.unist.hr/islandora/object/efst\%3A1 177/datastream/PDF/view (10 November 2017).

18. Liébana-Cabanillas, F., Marinković, V., Kalinić, Z. (2017), "A SEM-neural network approach for predicting antecedents of m-commerce acceptance", International Journal of Information Management, Vol. 37, No. 2, pp. 14-24.

19. Makarević, N. (2016), "Perceptions towards IT Security in Online Banking: Croatian Clients vs. Clients of Bosnia and Herzegovina", Journal of Finance \& Banking Studies, Vol. 5, No. 1, pp. 1-15.

20. Milanović Glavan, Lj., Ćibarić, A. (2015), "Analiza korištenja Internet bankarstva među studentskom populacijom u Republici Hrvatskoj" (Analysis of the use of Internet banking among student population in the Republic of Croatia), in Zlatović, D. (Ed.), Proceedings of The Polytechnic in Šibenik, No. 3-4, pp. 69-79.

21. Mood, C. (2010), "Logistic Regression: Why We Cannot Do What We Think We Can Do, and What We Can Do About It", European Sociological Review, Vol. 26, No. 1, pp. 67-82.

22. Patsiotis, A. G., Hughes, T., Webber, D. J. (2012), "Adopters and non-adopters of internet banking: a segmentation study", International Journal of Bank Marketing, Vol. 30, No. 1, pp. 20-42.

23. Pikkarainen, T., Pikkarainen, K., Karjaluoto, H., Pahnila, S. (2004), "Consumer acceptance of online banking: an extension of the technology acceptance model", Internet Research, Vol. 14, No. 3, pp. 224-235.

24. Polasik, M., Wisniewski, T. P. (2009), "Empirical analysis of internet banking adoption in Poland", International Journal of Bank Marketing, Vol. 27, No. 1, pp. 32-52.

25. Sadeghi, T., Farokhian, S. (2011), "Services quality model for online banking services by behavioral adoption theories and comparative study", African Journal of Business Management, Vol. 5, No. 11, pp. 4490-4499.

26. Safeena, R., Date, H., Hundewale, N., Kammani, A. (2013), "Combination of TAM and TPB in Internet banking Adoption", International Journal of Computer Theory and Engineering, Vol. 5, No. 1, pp. 146-150.

27. Safeena, R., Kammani, A., Date, H. (2014), "Assessment of Internet Banking Adoption: An Empirical Analysis", Arabian Journal for Science and Engineering, Vol. 39, No. 2, pp. 837849. 
28. Shelby, L. B. (2011), "Beyond Cronbach's Alpha: Considering Confirmatory Factor Analysis and Segmentation", Human Dimensions of Wildlife: An International Journal, Vol. 16, No. 2 , pp. 142-148.

29. Taherdoost, H., Sahibuddin, S., Jalaliyoon, N. (2014), "Exploratory factor analysis: Concepts and theory", in Balicki, J. (Ed.), Advances in Applied and Pure Mathematics, Proceedings of the 2nd International Conference on Mathematical, Computational and Statistical Sciences (MCSS '14); Proceedings of the 7th International Conference on Finite Differences, Finite Elements, Finite Volumes, Boundary Elements (F-and-B '14), Gdansk, Poland, WSEAS Press, pp. 375-382.

30. Tavakol, M., Dennick, R. (2011), "Making sense of Cronbach's alpha", International Journal of Medical Education, Vol. 2, pp. 53-55.

31. Teddlie, C., Yu, F. (2007), "Mixed Methods Sampling: A Typology with Examples", Journal of Mixed Methods Research, Vol. 1, No. 77, pp. 77-100.

32. Tokić, I. (2014), "Usage of the Internet Banking among Legal Entities in the Republic of Croatia", Master thesis, University of Split, Faculty of Economics, Business and Tourism.

33. Venkatesh, V., Davis, F. D. (1996), "A model of the antecedents of perceived ease of use: development and test", Decision Sciences, Vol. 27, No. 3, pp. 451-481.

34. Yiu, C. S., Grant, K., Edgar, D. (2007), "Factors affecting the adoption of Internet Banking in Hong Kong - implications for the banking sector", International Journal of Information Management, Vol. 27, No. 5, pp. 336-351.

35. Yoon, H. S., Barker Steege, L. M. (2013), "Development of a quantitative model of the impact of customers' personality and perceptions on Internet banking use", Computers in Human Behavior, Vol. 29, No. 3, pp. 1133-1141.

36. Yousafzai, S., Yani-de-Soriano, M. (2012), "Understanding customer-specific factors underpinning internet banking adoption", International Journal of Bank Marketing, Vol. 30, No. 1, pp. 60-81. 


\section{About the authors}

Marija Vuković, mag.oec. is a Teaching Assistant at the Faculty of Economics, Business and Tourism, University of Split, Department of Quantitative Methods. She currently teaches several statistical courses and attends postgraduate studies. She is a member of Croatian Operational Research Society, Croatian Statistical Association and American Statistical Association. Her main fields of interest are statistical methods in economics and business statistics. The author can be contacted at marija.vukovic@efst.hr.

Snježana Pivac, Ph.D. is a Full Professor at the Faculty of Economics, Business and Tourism, University of Split, Department of Quantitative Methods. She received PhD in Quantitative Methods in Economy at the Faculty of Economics and Business Zagreb. She was the correspondent for Croatia for the International Federation of Operational Research Societies, the member of Croatian Operational Research Society, Croatian Statistical Association and American Statistical Association. Her main research interests are statistical methods in economy, business statistics, econometric modelling and actuarial mathematics. She is Co-Editor of Croatian Operational Research Review (CRORR), ISSN 1848-0225. The author can be contacted at snjezana.pivac@efst.hr.

Duje Kudid, mag.oec graduated IT Management at the study of the Business Economy at the Faculty of Economics, Business and Tourism at the University of Split.

He works in SeekandHit in Split, Croatia. SeekandHit is a technology company specializing in digital marketing, advertising, analytics and data processing. The author can be contacted at duje.kundid@gmail.com. 